\title{
Psikologi dan Penerimaan Warga Emas di Kompleks Warga Emas al-Jenderami
}

\author{
Nor Raudah Siren \\ Universiti Malaya, raudah68@um.edu.my
}

\begin{abstract}
Abstrak
Warga emas merupakan insan istimewa yang sudah berada di penghujung usia sebagaimana yang dijelaskan dalam Surah al-Hajj ayat 5. Faktor usia telah mempengaruhi emosi, fizikal, intelektual dan kerohaniannya serta persediaan mereka untuk menghadapi alam selepas kehidupan. Penulisan ini bertujuan memahami psikologi warga emas yang tinggal di Kompleks Warga Emas al-Jenderami (YAJ) walaupun terpaksa meninggalkan keluarga yang dikasihi. Aspek psikologi yang dianalisis ialah faktor memilih untuk tinggal di YAJ, penerimaan anakanak terhadap keputusan mereka, emosi semasa tinggal di YAJ, pandangan terhadap pengajian, pandangan terhadap kemudahan, hubungan dengan rakan sebaya, hubungan keluarga dan perasaan meninggalkan keluarga. Kajian ini menggunakan kajian lapangan dengan metode temubual berstruktur tetapi santai kepada warga emas yang bersedia bekerjasama. Temubual juga dilakukan terhadap pengurusan YAJ untuk mendapatkan latar belakang warga emas dan YAJ secara dekat. Kajian juga memilih metode pemerhatian dengan mengikuti program bersama warga emas. Secara keseluruhannya, warga emas mencapai tujuannya sepanjang berada di YAJ iaitu meningkatkan ilmu, mudah beribadat dan ketenangan hidup menghadapi hari-hari tua mereka.
\end{abstract}

Kata kunci: warga emas, psikologi warga emas, penerimaan dakwah, pendekatan dakwah

\section{Psychology and Acceptance of the Senior Citizens at the Kompleks Warga Emas al-Jenderami}

\begin{abstract}
Senior citizens are special group of people who are at the final stage of their age as described in Surah al-Hajj verse 5. The age factor has affected their emotion, physic, intellect and spirituality in preparation of afterlife. This study aims to understand the psychology of the elderly who live at the Kompleks Warga Emas al-Jenderami (YAJ), even though they have to leave their family. The psychological aspects analysed are their reason to live in YAJ, children's response to their decisions, emotions during living at YAJ, views on education, facilities, relationships with peers and family and feeling about leaving the family. This study employs
\end{abstract}


field studies tools such as structured but relaxed interviews with senior citizens who are willing to cooperate. Interviews are also conducted with management of YAJ to get more information on the background of the elderly and YAJ. The study is also done through observation and participation in programs with the research target. Overall, this study finds that senior citizens achieve their goals during their stay at YAJ which are to gain more knowledge, worship and quiet life of their remaining days.

Keywords: senior citizens, senior citizen psychology, acceptance of da'wah, methodology of da'wah

\section{Pendahuluan}

Penciptaan kejadian alam dan manusia merupakan bukti kepada hakikat kewujudan Allah SWT. Melalui pengamatan terhadap kehalusan dan kesempurnaan kejadian tersebut, manusia yang berfikir akan mendapati adanya satu kuasa yang amat agung sehingga mampu menjadikan alam dan manusia dengan segala keunikan dan kehalusannya, yang tidak berupaya dilawan oleh akal dan kuasa manusia. Allah SWT menciptakan manusia serta memahami hakikat penciptaan-Nya, asal kejadian, kelemahan dan kesempurnaannya, tugas dan tanggungjawab, kedudukan manusia, matlamat kewujudannya dan berpengetahuan dalam segala aspek yang memperkatakan tentang hakikat kejadian manusia itu sendiri. Allah SWT berfirman:

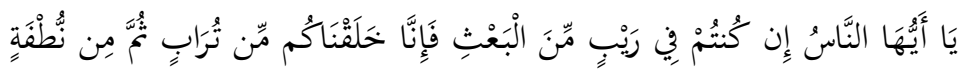

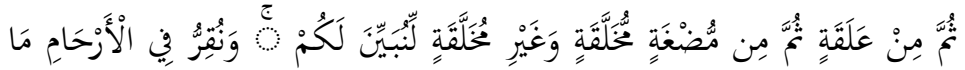

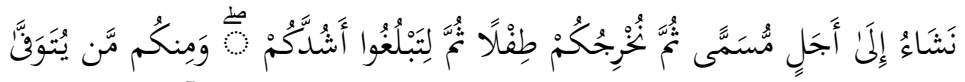

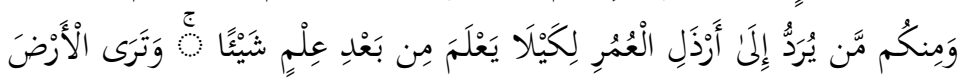

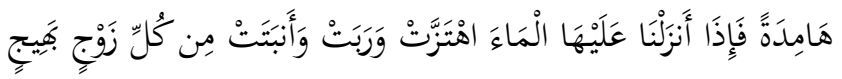

$$
\begin{aligned}
& \text { al-Hajj 22:5 }
\end{aligned}
$$

Terjemahan: Wahai umat manusia, sekiranya kamu menaruh syak (ragu-ragu) tentang kebangkitan makhluk (hidup semula pada hari kiamat), maka (perhatilah kepada tingkatan kejadian manusia) kerana sebenarnya Kami telah menciptakan kamu dari tanah, kemudian dari setitik air benih, kemudian dari sebuku darah beku, kemudian dari seketul 
daging yang disempurnakan kejadiannya dan yang tidak disempurnakan; (Kami jadikan secara yang demikian) kerana Kami hendak menerangkan kepada kamu (kekuasaan Kami); dan Kami pula menetapkan dalam kandungan rahim (ibu yang mengandung itu) apa yang Kami rancangkan hingga ke suatu masa yang ditentukan lahirnya; kemudian Kami mengeluarkan kamu berupa kanak-kanak; kemudian (kamu dipelihara) hingga sampai ke peringkat umur dewasa; dan (dalam pada itu) ada di antara kamu yang dimatikan (semasa kecil atau semasa dewasa) dan ada pula yang dilanjutkan umurnya ke peringkat tua nyanyuk sehingga ia tidak mengetahui lagi akan sesuatu yang telah diketahuinya dahulu. Dan (ingatlah satu bukti lagi); Engkau melihat bumi itu kering, kemudian apabila Kami menurunkan hujan menimpanya, bergeraklah tanahnya (dengan tumbuhtumbuhan yang merecup tumbuh), dan gembur membusutlah ia, serta ia pula menumbuhkan berjenis-jenis tanaman yang indah permai.

Ayat di atas menjelaskan bahawa proses kejadian manusia dan perkembangannya bermula dari Nabi Adam a.s yang diciptakan dari tanah. Kemudian manusia diciptakan dari setitis air mani dan disempurnakan kejadiannya di alam rahim untuk lahir dan membesar hinggalah ke peringkat umur yang dikehendaki oleh Allah SWT. Namun begitu, terdapat manusia yang terus hidup lama hinggalah ke alam tua dan nyanyuk. Walau bagaimanapun setiap perkembangan hidup manusia tersebut mempunyai sebab dan tanggungjawab tersendiri di sisi Allah SWT.

\section{Konsep Warga Emas}

Dasar Warga Tua Negara menjelaskan bahawa warga emas atau warga tua adalah mereka yang umur melebihi 60 tahun. Di negara maju dan membangun, takrifan warga tua ialah mereka yang melebihi 65 tahun (disebabkan oleh taraf ekonomi, pendidikan, taraf kesihatan yang lebih tinggi, kemudahan perubatan yang lebih mantap dan jangka hayat yang lebih panjang, berbanding dengan negara yang sedang membangun). Secara umumnya, warga tua ditakrifkan sebagai golongan berumur 60 tahun ke atas 
berpandukan kepada takrifan yang dibuat di World Assembly on Aging (1982) di Vienna.

Di Malaysia, warga tua atau juga dikenali sebagai warga emas dijangka akan mencecah 3.2 juta atau 9.5 peratus daripada penduduk negara ini menjelang tahun 2020 berbanding 2.1 juta (7.3 peratus) tahun 2011, berikutan penurunan kesuburan dan peningkatan jangka hayat di negara ini. Berdasarkan fenomena berkenaan dan pertambahan warga tua itu juga memungkinkan Malaysia mencapai status negara tua seperti negara maju lain terutama negara Barat dengan purata 15 peratus jumlah penduduk Malaysia berusia 60 tahun ke atas menjelang 2030. Malah, jangka hayat penduduk Malaysia dilihat semakin meningkat berdasarkan kajian pada 2009 iaitu berusia 72.6 bagi lelaki dan wanita berusia 77.5 berbanding 63.5 (lelaki) dan 67.1 (wanita) pada 1980. ${ }^{1}$

Sebagai perbandingan, statistik 2005 menunjukkan terdapat kira-kira 1.66 juta penduduk di Malaysia yang berusia 60 tahun ke atas yang boleh dikategorikan sebagai golongan tua atau warga emas. Bilangan warga emas ini dijangka meningkat berdasarkan unjuran pada 1991 dan 2000 yang masing-masing sejuta atau 5.9 peratus serta 1.42 juta orang atau 6.1 peratus daripada jumlah penduduk Malaysia ketika itu. Bancian pada 2004 pula menunjukkan tujuh peratus atau kira-kira 1.75 juta daripada penduduk negara ketika itu terdiri daripada warga emas. Ini berkait rapat dengan kajian jangka hayat penduduk Malaysia yang menunjukkan jangka hayat lelaki meningkat daripada 66.5 tahun kepada 70.8 tahun dan bagi wanita pula, jangka hayat mereka terus meningkat daripada 71 tahun kepada 75.5 tahun. $^{2}$

Menurut buku Pemakanan dan Penilaian Kesihatan Warga Tua (2007), sejak 1960-an terdapat peningkatan jumlah warga tua di Malaysia kerana penurunan kadar kelahiran dan mortaliti, peningkatan kawalan penyakit berjangkit serta kemudahan kesihatan yang bertambah baik. Peningkatan jangka hayat penduduk ini menyebabkan kumpulan umur yang lebih tua

1 Laman sesawang Harian Metro, dicapai pada 15 Julai 2011, http://www.hmetro.com.my/myMetro/articles/Minda_Menjaminkebajikanwarg aemas/Article/index_html.

2 Laman sesawang Harian Metro, dicapai pada 15 Julai 2011, http://www.hmetro.com.my/myMetro/articles/Minda_Menjaminkebajikanwarg aemas/Article/index_html. 
meningkat secara signifikan dan ianya dikaitkan dengan masalah malnutrisi iaitu kekurangan zat makanan atau pemakanan yang berlebihan. Mereka yang mengambil diet yang kurang zat akan menyebabkan keabnormalan metabolisme, perubahan fisiologi, kemerosotan fungsi tisu dan organ serta kehilangan jisim tubuh. ${ }^{3}$

Sehubungan itu, satu Dasar Warga Tua Kebangsaan (DWTK) diperkenalkan bertujuan mewujudkan masyarakat warga tua sejahtera, bermaruah, bermartabat diri yang tinggi, dengan mengoptimumkan potensi diri mereka dan menentukan mereka menikmati semua peluang di samping mendapat penjagaan dan perlindungan sebagai ahli keluarga, masyarakat dan negara. Perlu diingat warga tua juga adalah penyumbang kepada produktiviti negara dan mempunyai hak, kehendak serta kepentingan sama seperti warga lain di negara kita. ${ }^{4}$

Oleh itu, dasar ini akan memastikan objektif untuk meningkatkan kehormatan, harga diri dan martabat diri warga tua dalam keluarga, masyarakat serta negara terlaksana dengan perancangan serta pelan jangka panjang yang sistematik. Pada masa sama berusaha memajukan potensi warga tua dalam segala aspek agar mereka terus aktif dan produktif dalam pembangunan negara serta mewujudkan pelbagai peluang bagi membantu mereka terus hidup berdikari dan berdaya saing dalam apa jua bidang yang diceburi. Di samping itu, dasar berkenaan juga bertujuan menggalakkan pewujudan dan menyediakan kemudahan yang tertentu demi menjamin penjagaan dan perlindungan warga tua di negara ini ke arah memastikan kebajikan serta kesejahteraan hidup mereka terpelihara. ${ }^{5}$

Biarpun rata-rata golongan ini telah bersara, dan menghabiskan hampir sepenuh masanya di rumah sahaja, namun tidak bererti golongan ini sekadar bersikap pasif atau dilabelkan sebagai kurang produktif. Warga emas masih berpeluang untuk bergiat aktif melibatkan diri dalam pembangunan negara mengikut kebolehan dan keupayaan masing-masing. Lantaran itu Kompleks

3 Suzana Shahar et al., Pemakanan dan Penilaian Kesihatan Warga Tua (Bangi: Penerbit Universiti Kebangsaan Malaysia, t.t.), 1.

4 Laman sesawang Jabatan Kebajikan Masyarakat, dicapai pada 2 April 2012, http://www.jkm.gov.my.

5 Laman sesawang Jabatan Kebajikan Masyarakat, dicapai pada 2 April 2012, http://www.jkm.gov.my. 
Warga Emas Al-Jenderami di bawah Yayasan Al-Jenderami (YAJ) telah menyahut cabaran untuk meletakkan warga emas di tempat yang sesuai bagi mempersiapkan diri menuju ke alam akhirat.

\section{Kompleks Warga Emas al-Jenderami}

Yayasan al-Jenderami adalah merupakan satu badan bukan kerajaan (NGO) ditubuh pada tanggal 23 Jun 2003 di bawah Akta Syarikat 1965 No Syarikat 619317-K. Dikecualikan dari cukai pendapatan di bawah seksyen 44(6), Akta Cukai pendapatan 1967, rujukan LHDN.01/35/42/51/179-6.5583. ${ }^{6}$

Yayasan ini telah menjalankan aktiviti amal dan kebajikan lebih daripada 15 tahun. Ia ditubuhkan bagi merealisasikan wawasan kerajaan dalam memberi perkhidmatan kepada masyarakat Malaysia amnya selaras dengan Dasar Sosial Negara, Dasar Warga Emas/Tua dan Dasar Keluarga Negara yang bermatlamatkan ke arah pembangunan seimbang. ${ }^{7}$

Bermula dengan sebuah pusat pengajian Islam berteraskan sistem tradisional di Desa Jenderam, Selangor Darul Ehsan. Kini YAJ telah dihimpit oleh rangkaian pembangunan moden di pinggir Pusat Pentadbiran Kerajaan Persekutuan Putrajaya, Cyberjaya, Kuala Lumpur International Airport (KLIA) dan Koridor Raya Multimedia (MSC). Lokasi penempatan YAJ yang strategik ini telah mencetuskan anjakan paradigma dan mengubah pusat ini menjadi sebuah yayasan dengan struktur organisasi yang lebih tersusun sebagai langkah untuk memastikan ia mengikuti peredaran masa dan tuntutan persekitaran. Walau bagaimanapun, Yayasan al-Jenderami tetap kekal sebagai sebuah organisasi yang berpegang teguh pada landasan Islam. ${ }^{8}$

Di Kompleks Yayasan ini juga tersedia kedai koperasi bagi memenuhi keperluan penduduk termasuk warga emas

6 Lihat Risalah Yayasan al-Jenderami. Lihat juga Masitah Mohd Ali, "Yayasan al-Jenderami dan Sumbangannya dalam Pembangunan Insan" (Kajian Ilmiah, Jabatan Dakwah Dan Pembangunan Insan, Akademi Pengajian Islam, Universiti Malaya, 2008), 45.

7 Ida Zulaidah Lutfi Hakim, "Laporan Praktikum al-Jenderami, Kg Baru Jenderam Hulu, Dengkil, Selangor" (Projek Sarjana, Fakulti Sains Sosial dan Kemanusiaan, Universiti Kebangsaan Malaysia, 2005), 5.

8 Laman sesawang Yayasan Al-Jenderami, dicapai pada 17 Jun 2012, http://www.aljenderami.com.my. 
mendapatkan barang keperluan harian. Selain itu, pakaian diuruskan oleh warga emas sendiri kecuali mereka yang tidak mampu membasuh akan diuruskan oleh pihak YAJ. Walau bagaimanapun ada juga pihak yang bersedia menjadi sukarelawan untuk menyumbang khidmat bagi membasuh pakaian warga emas tersebut. Penyediaan pelbagai kemudahan di Kompleks Warga Emas YAJ ini, membolehkan para ibu merasa lebih khusyuk menimba ilmu kerana suasana dan keadaan masyarakat yang mementingkan sifat tolong-menolong serta pelbagai program pengajian yang diadakan sesuai dengan peringkat umur dan tahap kefahaman mereka. ${ }^{9}$ Tuan Haji Roee menjelaskan;

"Persekitaran YAJ dipastikan sentiasa indah dan bersih. Hal ini ditonjolkan sebagai amalan sunnah Rasulullah yang menggalakkan umatnya menjaga kebersihan. Selain itu, suasana Madinah yang diwujudkan bertujuan untuk menarik perhatian masyarakat luar untuk datang berkunjung ke YAJ. YAJ juga menyediakan kemudahan penginapan untuk masyarakat awam yang datang di samping menawarkan kelas agama serta sambutan hari kebesaran." 10

\section{Metodologi Kajian}

Kajian ini menggunakan kajian lapangan untuk mengumpul data dianalisis secara kualitatif bagi menghuraikan dapatan kajian. Metode pengumpulan data yang dilakukan ialah;

1. Temubual pihak pengurusan Yayasan al-Jenderami untuk memahami situasi warga emas, mendapatkan maklumat warga emas dan pengisian serta kemudahan yang disediakan oleh YAJ untuk warga emas. Temubual dilakukan dengan Tuan Haji Roee Bin Abidin, Pengurus YAJ dan Tuan Haji Shahirul Azmar, COO YAJ.

2. Temubual berstruktur tetapi secara santai (bersembang) dengan 33 orang warga emas yang bersedia untuk ditemubual. Tidak semua warga emas sedia ditemuramah kerana tidak mahu diganggu dan ingin bersendirian di waktu rehat mereka. Warga emas yang bersedia ditemubual dipilih hasil perbualan tidak

9 Laman sesawang Yayasan Al-Jenderami, dicapai pada 17 Jun 2012, http://www.aljenderami.com.my.

${ }^{10}$ Roee Bin Abidin (Pengurus YAJ), dalam temubual dengan penulis, 16 Jun 2012. 
formal semasa bertembung di perjalanan pergi dan balik ke masjid, semasa makan dan semasa bertembung di majlis ilmu. Nombor rumah mereka diambil dan ziarah dilakukan untuk menemuramah mereka pada waktu rehat iaitu waktu pagi (11.00 - 12.00) dan waktu petang (5.00 hingga 6.00). Jadual pengajian mereka amat ketat dengan waktu rehat yang pendek menghadkan sesi temuramah. Temuramah juga dapat dilakukan kerana program khidmat masyarakat mahasiswa yang dilaksanakan pada hari tersebut memudahkan warga emas untuk tidak perlu memasak makan tengahari dan makan malam mereka. Soalan disusun secara berstruktur untuk kemudahan analisis data dilakukan dan memastikan tiada bahagian yang tertinggal.

3. Pemerhatian secara langsung dengan mengikuti program khidmat masyarakat mahasiswa bersama warga emas selama dua hari di YAJ. Pemerhatian dilakukan bagi merasai dan melihat sendiri situasi kehidupan warga emas di YAJ di samping melihat dan meninjau kemudahan yang disediakan.

Berdasarkan data yang dikumpul, analisis secara kualitatif dilakukan berdasarkan kaedah induktif dan deduktif bagi memahami data. Berdasarkan analisis, kajian mendapati terdapat data-data yang saling berkaitan antara tiga sumber primer yang diperolehi, lalu metode komparatif dilakukan untuk mendapatkan satu kesimpulan terhadap data-data tersebut.

\section{Faktor Warga Emas Tinggal di Komplek Warga Emas al- Jenderami}

Menurut Shahirul Azma, ${ }^{11}$ seramai $90^{12}$ orang tinggal di Kompleks Warga Emas al- Jenderami. Kehadiran mereka ke pusat pengajian tersebut membawa pelbagai tujuan dan antara perkara utama yang ditekankan ialah inginkan kehidupan yang aman dan tenteram untuk beribadat kepada Allah SWT tanpa gangguan dari anak cucu. Walau bagaimanapun, kajian mendapati terdapat tiga aspek utama faktor warga emas memilih untuk tinggal di Kompleks Warga Emas al-Jenderami.

\footnotetext{
${ }^{11}$ Shahirul Azmar Bin Ishak (COO YAJ), dalam temubual dengan penulis, 16 Jun 2012.

${ }^{12}$ Senarai nama penghuni Kompleks Warga Emas Al-Jenderami, tahun 2012.
} 


\section{Kemudahan Beribadat}

Keseluruhan responden mengakui tujuan mereka tinggal YAJ ialah untuk mengurangkan urusan dunia dan menumpukan perhatian untuk melaksanakan ibadat sebagai bekalan menuju ke akhirat.

Selama ini mereka kurang masa untuk beribadat kerana kekangan kerja atau kekangan membesarkan anak. Malah kedapatan warga emas yang menjaga cucu kerana anaknya keluar bekerja. Oleh itu, diwaktu usia yang sudah lanjut, mereka mahu berehat dari kesibukan rumah tangga sementelah pula sesudah kematian suami. Maka, YAJ adalah tempat yang paling sesuai memenuhi keinginan tersebut. Menurut Puan Som Binti Jantan, beliau memilih tinggal di YAJ setelah suaminya meninggal dunia. Setelah mencari di internet, beliau mendapat maklumat tentang YAJ. Perkara ini diakui juga oleh Puan Siti Saidin yang tinggal di YAJ setelah kematian suaminya.

Kemudahan untuk beribadat di YAJ juga antara faktor utama mereka memilih untuk tinggal di situ. Kedudukan rumah yang selesa dan berhampiran dengan masjid memudahkan mereka untuk mengamalkan solat berjemaah secara konsisten. Puan Seribanun Kalam mengatakan YAJ memiliki kemudahan yang lengkap. Hal ini menurut Puan Arbaiyah $\mathrm{Hj}$ Sukeri memudahkan mereka untuk sentiasa mengamalkan solat berjemaah di masjid.

Di YAJ juga, mereka boleh melakukan ibadat yang lain dengan lebih tenteram seperti membaca al-Qur'an, berpuasa sunat, berzikir dan bermunajat kepada Allah. Kehidupan persekitaran yang dipenuhi dengan suasana ibadat menjadikan jiwa mereka semakin tenteram dan selesa, lebih-lebih lagi suasana persekitaran yang diwujudkan oleh YAJ seperti di Kota Madinah. Puan Rapeah Mohd Juah mengatakan tempat tersebut sesuai untuk mencari ketenangan dalam beribadat. Manakala Puan Wan Fatimah Abdul Kadir juga memberikan pendapat yang sama bahawa tempat tersebut sesuai untuk beribadat dengan tenang tanpa gangguan dari mana-mana terutama anak cucunya.

\section{Kemudahan Menuntut Ilmu Agama}

Semua responden juga mengakui tujuan mereka datang ke YAJ ialah untuk menuntut ilmu agama. Mereka sedar tugas menuntut ilmu adalah dituntut oleh Islam. Bahkan, di sinilah peluang dan 
ruang untuk mereka mendalami ilmu agama yang selama ini terlepas kerana kesibukan kerja dan mendidik anak. Masa emas inilah peluang yang amat sesuai digunakan untuk mendalami ilmu agama, terutama membaca al-Qur'an dengan bacaan tajwid dan makhraj yang betul.

Semua responden juga mengakui, di YAJ, kelas al-Qur'an dijalankan secara berkumpulan dan akan diketuai oleh warga emas yang fasih membaca al-Qur'an. Ini bermakna, kelas al-Qur'an diajar oleh rakan sebaya mereka. Kebanyakan warga emas yang mengetuai kelas al-Qur'an adalah bekas guru al-Qur'an atau guru agama.

Kelas-kelas pengajian yang dijalankan di YAJ pula lebih tertumpu pada ilmu-ilmu tauhid, fekah dan tasawuf. Kitab-kitab tertentu digunakan sebagai teks dan akan disampaikan oleh Syeikh al-Hafiz, iaitu pengasas YAJ atau ulama-ulama yang dijemput dari luar seperti dari Timur Tengah, Indonesia, Thailand dan sebagainya. ${ }^{13}$

Puan Jariah Bt Mat Saleh, mengakui dia memilih tinggal di Kompleks warga emas tersebut untuk mendalami ilmu agama dan mendapatkan ketenangan jiwa. Puan Ramlah Haji Manap juga mengatakan tujuan utama beliau ke YAJ ialah untuk mendalami ilmu agama. Puan Siti Asma Hashim juga bersetuju tempat tersebut sesuai untuk mendalami ilmu agama dan ilmu akhirat sebanyak mungkin.

\section{Tempat Tinggal yang Kondusif Bersama Komuniti Rakan Sebaya}

Di YAJ, mereka dapat berkumpul dan berbincang bersama rakan sebaya. Kehidupan bersama masyarakat dan persekitaran dengan rakan-rakan yang seusia mereka memberi keselesaan dan tiada masalah jurang pandangan dan perasaan. Masing-masing saling memahami keperluan hidup mereka. Menurut Puan Siti Mohamed Isa, perhubungan antara warga emas di situ baik dan saling memahami antara satu sama lain.

Di YAJ, warga emas ditempatkan di rumah-rumah mengikut fasa. Setiap rumah akan didiami antara seorang hingga dua orang sahaja. Kelengkapan perabut dan dapur juga memudahkan warga

${ }^{13}$ Roee Bin Abidin (Pengurus YAJ), dalam temubual dengan penulis, 16 Jun 2012. 
emas untuk mengurus diri mereka sendiri. Menurut Tuan Haji Roee, sebelum warga emas diterima masuk, mereka akan disoal bagi menguji kewarasan pemikiran mereka. Mereka juga dikehendaki berjalan sendiri untuk memperlihatkan keupayaan mereka mengikuti pengajian dan mengurus diri sendiri. Hal ini kerana YAJ bukan pusat jagaan warga emas tetapi adalah pusat pengajian. ${ }^{14}$

Selain tempat tinggal, warga emas juga diberi peluang untuk memasak sendiri makanan mereka. Malah mereka seringkali bertukar-tukar makanan dengan rakan sebaya yang berasal dari pelbagai negeri. Kadang-kala mereka memasak beramai-ramai untuk dikongsi bersama. Situasi ini mewujudkan ukhuwwah yang akrab antara warga emas. Menurut Hjh Shahimah Puteh Aziz, beliau memilih untuk memasak sendiri dan diakui juga oleh Puan Siti Binti Mohamed Isa.

Bagi warga emas yang tidak mampu memasak sendiri makanannya, mereka boleh membeli atau menempah makanan dari pihak YAJ. Kemudahan memasak bagi warga emas turut disediakan kerana terdapat juga warga emas yang uzur dan berkerusi roda. Menurut Siti Asma Hashim, beliau menempah makanan untuk kemudahan dan menjimatkan masa. Hal ini turut dilakukan oleh Puan Ramlah Abd Rashid.

Di hujung minggu pula, anak-anak penghuni YAJ akan datang menziarahi mereka di YAJ dan membawa makanan untuk mereka. Oleh itu, bagi warga emas di YAJ, bekalan makanan dan minuman tidak menjadi masalah yang rumit.

\section{Penerimaan Awal Anak-anak Setelah Memilih Tinggal di Kompleks Warga Emas al-Jenderami}

Keputusan untuk tinggal di pondok pengajian warga emas merupakan keinginan yang tidak boleh dibendung lagi kerana alasan-alasan di atas. Ketika menyuarakan keinginan tersebut, pelbagai reaksi timbul daripada anak-anak mereka.

\section{Mendapat Sokongan Penuh}

Anak-anak begitu memahami keinginan ibu mereka lantaran mereka juga terlalu sibuk untuk melayan mereka di rumah.

\footnotetext{
${ }^{14}$ Roee Bin Abidin (Pengurus YAJ), dalam temubual dengan penulis, 16 Jun 2012.
} 
Kesunyian ibu yang tinggal di rumah sendirian ketika anak-anak keluar bekerja pastinya menimbulkan rasa kasihan. Oleh itu, apabila ibu mereka menyuarakan keinginan tersebut, anak-anak amat menyokong agar masa ibu mereka akan diisi dengan perkara yang lebih berfaedah. Hal ini diakui oleh Puan Siti Asma Hashim yang mengatakan anak-anak menyokong penglibatannya ke YAJ. Malah mereka yang mencarikan tempat di pusat pengajian tersebut. Begitu juga halnya dengan Puan Laily Rozita Abd Karim. Bagi Puan Rosmah $\mathrm{Hj}$ Suran pula, anak-anak tidak mempunyai masalah membenarkan beliau tinggal di situ kerana anak-anak mereka juga tinggal di sekitar Kuala Lumpur.

\section{Kurang Bersetuju}

Ada juga anak-anak yang ragu-ragu untuk membenarkan ibu mereka berjauhan dari mereka. Mereka tidak mahu dianggap sebagai anak derhaka oleh masyarakat kerana meninggalkan ibu mereka di tempat orang tua. Tetapi setelah menziarahi YAJ, barulah perasaan ragu-ragu tersebut terurai dan mereka membenarkan ibu mereka menetap di situ.

Menurut Puan Hajah Zawiyah pada mulanya anak-anak tidak setuju dengan pilihannya, tetapi apabila dia bersungguh-sungguh untuk ke YAJ barulah anak-anak membenarkannya. Begitu juga halnya dengan Puan Noralaini Hamzah yang terpaksa memujuk anak-anaknya dan membuat lawatan ke YAJ.

\section{Penentangan}

Terdapat juga warga emas yang mengatakan anak-anaknya menentang keputusannya untuk menetap di YAJ. Anak-anak risau dengan keselamatan dan kesihatan ibu mereka yang terpaksa menguruskan diri sendiri. Mereka juga tidak mahu ibu mereka berjauhan dari hidup mereka. Namun, setelah melihat persekitaran YAJ, barulah mereka membenarkan ibu mereka tinggal di YAJ. Hal ini diakui oleh Puan Hajah Mimi Mohd Din yang memang anak-anak menentang kehendaknya. Tetapi selepas memahami situasi di YAJ barulah mereka mengizinkan. Begitu juga dengan anak-anak Puan Rokiah Sulan. 


\section{Perasaan Tinggal di Kompleks Warga Emas al-Jenderami}

Keseluruhan responden berasa bersyukur dan gembira tinggal di YAJ. Kehidupan mereka di YAJ penuh dengan ketenangan dan pengisian yang baik. Hidup bermasyarakat dan suasana perkampungan memberi keselesaan. Antara perasaan yang dilahirkan sepanjang tinggal di YAJ ialah seperti berikut.

\section{Ketenangan}

Responden mengakui sepanjang tinggal di YAJ, hidup mereka semakin tenang. Mereka boleh menumpukan perhatian kepada ibadat dan merasa sentiasa dekat dengan Allah SWT. Mereka juga tidak perlu memikirkan masalah rumah tangga atau kehidupan dunia.

Menurut Puan Siti Saidin, beliau berasa gembira dan tenang tinggal di situ, begitu juga dengan perasaan adiknya yang tinggal bersamanya, Puan Siti Painah Saidin. Puan Zainab Samah pula mengatakan beliau merasa lebih dekat dengan Allah sepanjang tinggal di YAJ.

\section{Keseronokan}

Warga emas juga mengakui mereka seronok tinggal di YAJ. Keseronokan tersebut dirasai kerana di situ mereka boleh menuntut ilmu agama bersama rakan sebaya. Banyak ilmu agama yang dipelajari mampu membimbing dan membetulkan kesilapan ibadat sebelum ini. Mereka juga gembira kerana berkesempatan menuntut ilmu di hujung usia itu.

Menurut Puan Som Binti Jantan, beliau berasa gembira dan lebih tenang tinggal di YAJ berbanding kehidupannya sebelum ini. Malah keseronokan tersebut dapat dinikmati apabila menurut Hajah Mimi Mohd Din, ibadat mereka tiada gangguan.

\section{Perasaan Menyertai Kelas Pengajian}

Kesemua responden mengakui suka dan seronok mengikuti pengajian di YAJ. Bagi mereka, ilmu yang mereka perolehi tidak ditemui di tempat lain. Mereka juga berasa seronok kerana selain pengajian harian, mereka juga berpeluang menyambut hari-hari kebesaran Islam terutama Maulidur Rasul yang diadakan setiap bulan dan disertai oleh beribu-ribu orang. Tempat tinggal yang 
dipenuhi dengan majlis ilmu tersebut menjadikan rasa cinta kepada ilmu semakin bertambah.

Menurut Tuan Haji Roee, mereka mengadakan Majlis Maulidur Rasul setiap bulan untuk menyemarakkan rasa cinta kepada Rasul, mendengar Sirah Rasul dan berselawat beramairamai. Bagi YAJ, majlis mengingati Rasul bukan hanya pada tarikh kelahiran baginda sahaja. Beliau juga menjelaskan setiap kali majlis dijalankan, beribu-ribu orang dari pelbagai pelusuk negeri dan nusantara (Indonesia dan Thailand) berkumpul untuk berselawat, mendengar ceramah dan bersedekah. Biasanya, jamuan untuk majlis tersebut akan ditaja oleh pihak yang bermurah hati. ${ }^{15}$

\section{Keadaan Fizikal/Kekuatan Menyertai Setiap Kelas}

Kesihatan merupakan aspek yang penting untuk terus tinggal di YAJ dan menyertai kelas pengajian yang dijalankan. Memang tidak dinafikan dalam usia yang sudah lanjut, kesihatan warga emas tidak menentu. Malah, ramai dalam kalangan mereka mempunyai penyakit yang lazim dihidapi oleh warga emas iaitu darah tinggi, kencing manis, masalah jantung dan sakit lutut. Walau bagaimanapun keazaman dan semangat yang tinggi membolehkan mereka terus bertahan untuk mengikuti kelas pengajian walaupun menggunakan kerusi roda. Menurut Puan Mah Saad dan Puan Sarah Hussin mereka mengalami sakit lutut, pinggang dan mudah letih tetapi masih terus boleh bertahan untuk mengikuti pengajian di YAJ.

Menurut mereka, ramai dalam kalangan warga emas di YAJ masih sihat dan cergas. Mereka mampu mengikuti semua kelas pengajian yang dijalankan. Malah ada yang mengakui sejak tinggal di YAJ, kesihatan mereka bertambah baik dan ada yang memiliki kenderaan sendiri untuk bergerak ke mana-mana. Hal ini dinyatakan oleh Puan Arbaiyah $\mathrm{Hj}$ Sukeri bahawa sebelum ini kesihatannya tidak berapa baik tetapi apabila tinggal di YAJ semangat hidupnya bertambah kuat dan kesihatannya bertambah baik. Bagi Puan Siti Juhari Tansin pula, beliau memiliki kenderaan sendiri dan bebas untuk memandu apabila mempunyai urusan peribadi di luar seperti kenduri.

${ }^{15}$ Roee Bin Abidin (Pengurus YAJ), dalam temubual dengan penulis, 16 Jun 2012. 
Walau bagaimanapun, terdapat juga warga emas yang semakin uzur dan memerlukan bantuan untuk bergerak terutama untuk ke masjid. Walaupun kesihatan kurang memuaskan tetapi hasrat untuk menuntut ilmu terlalu mendalam. Hal ini diakui oleh Puan Seribanun Kalam yang mengatakan kesihatan kurang baik tetapi kekuatan hati untuk mencari ilmu terlalu mendalam menjadikannya terus bertahan. Melalui pemerhatian pula, terdapat seorang warga emas yang memiliki penjaga (maid) dari Indonesia untuk membantu menguruskan kehidupannya termasuk ke kelas pengajian menggunakan kerusi roda.

Walau bagaimanapun, ramai lagi warga emas yang mengakui masih sihat dan kuat selama tinggal di YAJ. Hal ini diakui oleh Puan Salmah Abdullah dan Puan Ramlah Haji Manap.

\section{Hubungan dengan Teman Serumah dan Warga Emas yang Lain}

Walaupun ukhuwah sudah terjalin di antara mereka, namun perbezaan budaya dan cara hidup kadang-kala menimbulkan konflik dengan teman serumah. Terdapat warga emas yang mengakui memiliki teman serumah yang panas baran, ada yang tinggal bersama ibu kandung sendiri, ada yang tinggal bersama adik ipar dan adik beradik yang saling memahami. Terdapat juga warga emas yang hanya tinggal sendiri kerana merasa selesa hidup begitu. Menurut Tuan Haji Roee, warga emas yang tinggal sendiri adalah warga emas yang membeli rumah tersebut dengan harga antara RM25 - 30 ribu. Rumah tersebut akan diwakafkan apabila mereka meninggal dunia kelak. ${ }^{16}$

Kehidupan bermasyarakat di YAJ bagai aur dengan tebing. Mereka hidup saling bantu-membantu dan saling memahami antara satu sama lain. Hubungan baik yang terjalin menjadikan mereka seolah-olah adik-beradik. Hal ini dipersetujui oleh Puan Puan Ramlah Said, Puan Wan Fatimah Abdul Kadir dan Puan Azizah bt Lom

Oleh kerana usia mereka tidak jauh berbeza, maka berkomunikasi menjadi mudah terutama untuk bercerita dan bertukar-tukar pengalaman dan rahsia hidup. Kemesraan yang terjalin menjadikan mereka mudah berkongsi perasaan dan

\footnotetext{
${ }^{16}$ Roee Bin Abidin (Pengurus YAJ), dalam temubual dengan penulis, 16 Jun 2012.
} 
pengalaman hidup. Puan Asiah Mohd Aman mengatakan mereka mudah untuk berkomunikasi antara satu sama lain.

\section{Ziarah Keluarga}

Tinggal di YAJ bukan bermakna mereka akan terus menetap tanpa dibenarkan balik menemui keluarga. Menurut Tuan Haji Roee, dalam setahun mereka dibenarkan bercuti selama 80 hari dan dikehendaki mengisi borang cuti apabila hendak menziarahi keluarga.

\section{Sebulan sekali bercuti}

Terdapat warga emas yang menetapkan sebulan sekali untuk bercuti pulang menziarahi anak cucunya. Hal ini kerana perasaan rindu kepada suasana keriuhan anak cucu. Anak mereka pula akan datang megambil mereka untuk pulang bersama kerana anak cucu mereka rindukan nenek mereka. Menurut Puan Ainun Abbas adalah menjadi kewajiban baginya untuk pulang sebulan sekali menjengok anak cucu. Hal ini juga diakui oleh teman serumahnya, Puan Rosiah Ibrahim.

\section{Cuti mengikut keperluan}

Terdapat juga responden yang bercuti ikut keperluan. Antaranya jika terdapat majlis tertentu di kampung seperti kenduri arwah, kenduri kahwin sanak saudara, atau cuti berhari raya. Hal ini diakui oleh Puan Som Jantan yang hanya akan pulang mengikut keperluan kerana cutinya dalam setahun di YAJ hanya 80 hari sahaja.

\section{Jarang bercuti}

Terdapat juga responden mengatakan beliau jarang bercuti kerana anak-anak sering datang menjengok mereka di situ. Kalaupun balik bercuti hanya 2 atau 3 bulan sekali atau balik hari kerana tidak mahu tertinggal kelas pengajian. Menurut Puan Jamilah Ali, beliau pulang apabila hari raya pertama sahaja. Puan Siti Juhari Tansin, pula mengatakan beliau jarang pulang ke rumah ahli keluarganya kerana tidak mahu ketinggalam pelajaran. Baginya, sampai bila asyik bersama anak cucu sedangkan pengajian lebih utama. 
Menurut Puan Siti Saidin, beliau jarang balik kerana anakanak yang sering menziarahinya. Manakala Puan Zainab Samah mengatakan sepanjang tinggal di YAJ selama 3 bulan ini, beliau baru pulang sekali. Bagi Puan Noralaini Hamzah, beliau menetapkan untuk pulang setahun dua kali sahaja.

\section{Perasaan Meninggalkan Keluarga}

Setiap hati seorang ibu adalah sama. Kasih sayang dan ingin sentiasa berada bersama keluarga tetap kuat dalam diri. Tetapi dengan perasaan yang bercampur-baur tersebut, mereka tetapkan hati dan nekad untuk meneruskan perjuangan mereka untuk menuntut ilmu dan beribadat dengan tenteram di YAJ. Kesedihan meninggalkan keluarga terubat apabila masa yang terluang telah digunakan sepenuhnya untuk menuntut ilmu dan beribadat. Hal ini dinyatakan oleh Puan Noralaini Hamzah yang kadang kala berasa sedih apabila mengingati anak cucunya. Begitu juga halnya dengan Puan Dasimah Johan.

Mereka juga menerima hakikat bahawa anak-anak mereka sudah berkeluarga dan mempunyai tanggungjawab tersendiri. Oleh itu, mereka redha untuk berjauhan dengan anak-anak sementelah pula anak-anak sering menjengok mereka terutama di hujung minggu. Hal ini ditegaskan oleh Puan Siti Juhari Tansin yang tidak mahu terikat dengan anak cucunya. Begitu juga pandangan Puan Ramlah Haji Manap yang menganggap anak cucu bukan matlamat utama kehidupan mereka sekarang.

Puan Siti Saidin dan Puan Naemah Yahya pula mengatakan perasaan nekad tinggal di situ menjadikannya tidak berasa sedih tinggal di situ. Begitu juga halnya dengan Puan Badriah Abd Razak yang mengatakan perasaan sedih yang datang akan hilang kerana keseronokan tinggal di YAJ.

\section{Pandangan tentang Kompleks Warga Emas al-Jenderami}

Secara keseluruhannya warga emas di YAJ menerima secara positif kehidupan mereka di situ.

\section{Penginapan}

Semua responden mengakui tempat tinggal yang disediakan kepada mereka selesa dan mencukupi. Hasil daripada pemerhatian, di dalam rumah warga emas tersebut terdapat sebuah bilik tidur, 
sebuah bilik air, ruang tamu (anggaran 4 x 5 kaki) dan dapur sebagaimana kehidupan keluarga biasa cuma ia agak kecil sesuai dengan warga emas untuk hidup berdua bersama teman sebiliknya. Menurut Puan Laily Abd Karim dan Hajah Shahimah Puteh Aziz tempat tinggal mereka sangat selesa dan mereka amat berpuas hati tinggal di situ.

\section{Pemakanan}

Terdapat pelbagai pandangan warga emas terhadap makanan yang disediakan di YAJ. Hal ini kerana kelainan cita rasa setiap individu warga emas. Terdapat warga emas yang suka dengan masakan di YAJ dan mengatakan sesuai dengan citarasa dan tahap kesihatan mereka. Hal ini diakui oleh Puan Siti Asma Hashim. Malah menurut Siti Binti Mohamed Isa makanan di situ baik, bersih dan suci. Manakala Puan Ramlah Said dan Puan Som Binti Jantan mengatakan makanan di situ sesuai untuk usia dan kesihatan warga emas.

Tetapi ada yang mengatakan kurang memuaskan kerana memang tidak suka orang lain masak untuk dirinya. Oleh itu, mereka memilih untuk memasak sendiri. Hal ini diakui sendiri oleh Puan Siti Saidin yang lebih suka memasak makanannya sendiri.

\section{Kemudahan}

Warga emas mengatakan kemudahan di YAJ adalah selesa, lengkap dan mencukupi. Hasil tinjauan, di YAJ terdapat Bistro, kilang roti, kedai koperasi menjual barangan dapur, menjual pakaian, makanan ringan, bahan minuman dan sebagainya sesuai dengan keperluan warga emas. Klinik juga terdapat di situ untuk mempastikan kesihatan warga emas dipantau dengan baik di samping kemudahan van untuk menghantar warga emas ke hospital bagi rawatan susulan atau kecemasan.

Dewan pengajian dan masjid yang luas dan bersih menjadikan suasana lebih selesa dan aman sepanjang mengikuti kelas pengajian dan melaksanakan ibadat. Malah hasil tinjauan kelengkapan alat pandang dengar menjadikan YAJ merupakan pondok moden yang setanding dengan institusi pengajian swasta yang lain. 
Hasil kajian mendapati semua responden selesa dan berpuas hati dengan kemudahan yang disediakan di YAJ. Menurut Tuan Haji Roee, kemudahan di YAJ disediakan secara moden dengan konsep penempatan dalam taman. Ahli lembaga YAJ dan penduduk persekitaran selalu datang bergotong-royong secara sukarela untuk membersihkan bangunan terutama selepas majlis. ${ }^{17}$

\section{Pengisian dan Penyertaan}

Semua responden mengakui pengajian di YAJ teratur dan mengandungi jadual yang padat. Pengisian yang padat menjadikan mereka akan berasa tertinggal jika bercuti lama. Kaedah pengajian yang disampaikan juga menarik dan mudah difahami, sesuai dengan usia mereka. Puan Siti Painah Saidin mengatakan kepadatan program di YAJ menjadikannya tidak pernah berasa bosan tinggal di situ. Antara program yang digemari ialah Tahlil Fida, berzanji dan majlis hari kebesaran Islam. Baginya pengisian kerohanian tersebut mampu mendidik hati dan jiwa.

Mereka mengakui YAJ mempunyai kaedah yang tertentu untuk membantu warga emas mendekatkan diri kepada Allah antaranya melalui zikir munajat dan lagu-lagu yang memuji Rasulullah SAW serta mengadakan majlis sempena hari kebesaran Islam seperti Israk Mikraj, Maulidur Rasul, Khadijah Kubro, sembelihan korban hari raya Aidiladha dan sebagainya.

Menurut Puan Mimi Mohd Din, kehidupannya terisi dengan zikir, mengaji dan selawat menjadikannya tidak lagi berfikir tentang dunia. Jika dulu dia sentiasa lalai dan leka dengan hal dunia, tetapi bila di usia tua ini dia tidak mahu lagi memikirkan pasal dunia lagi.

Menurut Puan Jareah Din, di YAJ mereka mempelajari beberapa zikir iaitu Ratib al-Attas ${ }^{18}$ dan Ratib al-Hadad. ${ }^{19}$

${ }^{17}$ Roee Bin Abidin (Pengurus YAJ), dalam temubual dengan penulis, 16 Jun 2012.

${ }^{18}$ Ratib Alattas menjadi amalan pengikut ratib hampir di seluruh dunia Islam terutama di Asia. Keluarga S.H Alattas merupakan keluarga ternama yang memiliki sekolah dan masjid serta menguasai perniagaan hartanah. Keluarga Alattas berasal dari Hadramaut, Yaman di Arab. Mereka juga mempunyai pertalian yang rapat antara satu sama lain kerana mereka datang dari keturunan Habib Omar Alattas Shafibul Ratib yang membawa Ratib Alattas tersebut. Laman sesawang Wikipedia, dicapai pada 29 Disember 2014, http://ms.wikipedia.org/wiki/Syed_Hussein_Al-Attas. Ahli Lujnah Fatwa 


\section{Penceramah}

Semua responden mengakui penceramah yang memberi kuliah dalam kelas pengajian YAJ memiliki ilmu yang tinggi dan berkarisma. Beliau juga seorang yang sangat baik dan berpengalaman serta mahukan yang terbaik untuk mengubah minda masyarakat terhadap pengajian pondok. Mereka juga mengakui kitab-kitab yang digunakan untuk kelas pengajian mudah dan jelas diikuti.

Menurut Tuan Haji Roee, ${ }^{20}$ selain penceramah yang dijemput dari luar terutama Syeikh atau al-Habib dari Indonesia dan Timur Tengah, Syeikh Hafiz ${ }^{21}$ sendiri menyampaikan kuliah pengajiannya.

berpendapat tiada halangan bagi beramal dengan Ratib Al-Attas. Lihat laman sesawang e-fatwa, http://www.e-fatwa.gov.my/fatwa-negeri/hukum-bacaanmajlis-ratib-al-attas-dan-asma-al-husna-0.

${ }^{19}$ Ratib al-Hadad ini disusun Abdullah bin Alwy Al-Hadad, dari keluarga Bani Sa'd yang tinggal di sebuah kampung di Shibam, Hadramaut. Tujuannya sebagai suatu wirid dan zikir untuk amalan penduduk kampungnya agar mereka dapat mempertahankan dan menyelamatkan diri dari ajaran sesat yang sedang melanda Hadhramaut ketika itu. Pertama kalinya Ratib ini dibaca di Kota Shibam dan dibaca di Masjid Al-Imam Al-Haddad di Al-Hawi, Tarim. Biasanya ratib ini dibaca berjamaah bersama doa dan nafalnya, setelah sholat Isya'. Pada bulan Ramadhan dibaca sebelum sholat Isya' untuk memberi kelonggaran waktu menunaikan solat Tarawih. Lihat laman sesawang Kecintaan dan Kasih Sayang Ahlul Baiyt, https://pondokhabib.wordpress.com/2011/10/08/sekilas-tentang-riwayat hiduppenyusun-ratib-al-haddad/

20 Laman sesawang Kecintaan dan Kasih Sayang Ahlul Baiyt, https://pondokhabib.wordpress.com/2011/10/08/sekilas-tentang-riwayat hiduppenyusun-ratib-al-haddad/

${ }^{21} \mathrm{Hj}$. Mohamad Hafidz yang lebih dikenali dengan nama Syeikh Hafiz AlJenderami berguru dengan Allahyarham $\mathrm{Hj}$. Hashim Abd. Aziz, dan beberapa ulama terkenal seperti Hj. Sulaiman Kuang, Kadi Sungai Besi, Kuala Lumpur. Beliau yang juga Pengerusi Badan Didikan Islam UDA (BADIM) bersama beberapa sahabatnya membina madrasah itu di Kampung Baru, Dengkil, Selangor kerana hendak melarikan diri dari kesesakan serta pembelajaran ilmu secara kelompok. Berkat kesungguhannya dan dengan izin Allah SWT, masyarakat sekitar termasuk ahli korporat menghulurkan derma serta sumbangan yang membolehkan beliau membina YAJ. Lihat laman sesawang http://ppm.org.my/pondok/bukupondok/selangor-w-p-kuala-lumpur/ yayasan-al-jenderami-dengkil/ 


\section{Penutup}

Secara umumnya, warga emas yang tinggal di YAJ memiliki matlamat atau tujuan yang sama iaitu mencari ketenangan hidup bagi membaiki ibadat dan dapat beribadat secara berterusan tanpa gangguan di samping menimba ilmu agama. Mereka berharap melalui ketenangan dan ketenteraman serta kemudahan yang disediakan di YAJ, mereka dapat melaksanakan ibadat dengan lebih khusyuk untuk mendekatkan diri kepada Allah SWT dan sebagai persediaan menghadapi alam kematian. Kemudahan yang disediakan oleh YAJ juga sesuai dengan keperluan warga emas yang tidak lagi mahu memikirkan kehidupan keduniaan.

\section{Bibliografi}

Ida Zulaidah Lutfi Hakim. Laporan Praktikum al-Jenderami, Kg Baru Jenderam Hulu, Dengkil, Selangor. Bangi: Projek Sarjana, Fakulti Sains Sosial dan Kemanusiaan, UKM, 2005.

Masitah Mohd Ali. "Yayasan al-Jenderami dan Sumbangannya dalam Pembangunan Insan." Kuala Lumpur: Jabatan Dakwah dan Pembangunan Insan, Akademi Pengajian Islam, Universiti Malaya, 2008.

Suzana Shahar et al. Pemakanan dan Penilaian Kesihatan Warga Tua. Bangi: Penerbit Universiti Kebangsaan Malaysia, t.t.

Laman sesawang Harian Metro, dicapai pada 15 Julai 2011, http://www.hmetro.com.my/myMetro/articles/Minda_Menjamin kebajikanwargaemas/Article/index_html.

Laman sesawang Kecintaan dan Kasih Sayang Ahlul Baiyt, https://pondokhabib.wordpress.com/2011/10/08/sekilas-tentangriwayat hidup-penyusun-ratib-al-haddad/

Laman sesawang Jabatan Kebajikan Masyarakat, dicapai pada 2 April 2012, http://www.jkm.gov.my.

Laman sesawang Yayasan Al-Jenderami, dicapai pada 17 Jun 2012, http://www.aljenderami.com.my.

Laman sesawang Wikipedia, dicapai pada 29 Disember 2014, http://ms.wikipedia.org/wiki/Syed_Hussein_Al-Attas.

Laman sesawang e-fatwa, http://www.e-fatwa.gov.my/fatwanegeri/hukum-bacaan-majlis-ratib-al-attas-dan-asma-al-husna-0. 
Raudah, Psikologi dan Penerimaan Warga Emas 